\title{
Assessment of antioxidative activity of alkaloids from Huperzia selago and Diphasiastrum complanatum using in vitro systems
}

\author{
Grzegorz A. Czapski ${ }^{1}$, Wojciech Szypułaㄹ ${ }^{2}$ Magdalena Kudlik ${ }^{1}$, Beata Wileńska ${ }^{3}$, Magdalena Kania ${ }^{3}$, \\ Witold Danikiewicz ${ }^{3}$, Agata Adamczyk ${ }^{1}$ \\ ${ }^{1}$ Mossakowski Medical Research Centre Polish Academy of Sciences, Warsaw, ${ }^{2}$ Medical University, Warsaw, ${ }^{3}$ Institute of Organic \\ Chemistry Polish Academy of Sciences, Warsaw, Poland
}

\begin{abstract}
Free radical-induced oxidative damage is implicated in the pathogenesis of neurodegenerative disorders, and antioxidants are presumably of therapeutic value in such diseases. Our previous data indicated that free radicals are strongly associated with brain aging and also play an important role in cytotoxicity of amyloidogenic proteins including $\alpha$-synuclein and amyloid $\beta$, which accumulate in brains during Parkinson's and Alzheimer's diseases. Disruption of the equilibrium of pro-oxidants and antioxidants results in oxidative stress that leads to the modification of DNA, proteins, carbohydrates, and lipids. It is widely accepted that antioxidants acting as radical scavengers protect the brain against oxidative damage in neurodegenerative diseases. Plant products are rich sources of phytochemicals and have been found to possess a variety of biological activities, including antioxidative potential.

The aim of this study was to analyse the antioxidative potential of alkaloid fractions from Huperzia selago and Diphasiastrum complanatum to protect macromolecules against oxidative damage. Thin layer chromatography (TLC) and high-performance liquid chromatography with diode array (HPLC-DAD) and electrospray ionisation mass spectrometric detection (ESI-MS/MS) were used to carry out a comprehensive characterization of alkaloids isolated from the plant material. The effect of the tested compounds on iron/ascorbate-induced lipid peroxidation and carbonyl group formation was analysed in the rat brain homogenate. Direct free radical scavenging (DPPH assay) and the effect on dityrosine formation were measured in cell-free systems.

Our results indicated that a number of alkaloid extracts at concentration of $25 \mu \mathrm{g} / \mathrm{ml}$ exhibited antioxidant activity as indicated by DPPH radical scavenging potential (up to 59\% inhibition) and inhibition of dityrosine formation. Selected alkaloid fractions provided significant protection against lipid peroxidation and protein oxidation in rat brain tissue homogenate, reducing iron/ascorbate-induced damage by about $20 \%$ and $76 \%$, respectively. Overall, the results indicated that selected alkaloids isolated from Huperzia selago effectively protect macromolecules from oxidative stress injury, which will give us an insight into the potential of alkaloids in terms of opening up a new therapeutic approach for oxidative stress-dependent disorders.
\end{abstract}

Key words: oxidative damage, carbonyl groups, lipid peroxidation, antioxidant, free radical scavenger, Huperzia selago, Diphasiastrum complanatum. 


\section{Introduction}

Free radical-induced oxidative damage is a component of the pathomechanism of many deleterious neurodegenerative disorders, such as Alzheimer's or Parkinson's disease [10]. The brain is an organ especially vulnerable to reactive oxygen species (ROS)-mediated injury for the following reasons: 1) high consumption of oxygen which is necessary for producing large amounts of ATP needed to maintain ion homeostasis, 2) neuronal membranes are rich in polyunsaturated fatty acids (PUFA), which are particularly vulnerable to free radical attack, 3) antioxidant defence mechanisms are modest, with low levels of catalase and glutathione peroxidase in particular, 4) the high $\mathrm{Ca}^{2+}$ traffic across neuronal membranes and interference of ion transport increase intracellular $\mathrm{Ca}^{2+}$, often leading to oxidative stress, 5) iron is accumulated in the brain, and brain damage readily releases iron ions capable of catalysing free radical reactions [17]. Disruption of equilibrium of pro-oxidants and antioxidants results in oxidative stress that leads to the modification of DNA, proteins, carbohydrates, and lipids. Free radicals attack the unsaturated fatty acids in the biomembranes, resulting in lipid peroxidation, decrease in fluidity, loss of enzyme and receptor activity, and damage to membrane proteins, and ultimately leading to cell damage. Lipid peroxidation is strongly associated with brain aging and neurodegenerative disorders. It is suggested that antioxidants, acting as radical scavengers, protect the brain against free radicals involved in the pathomechanism of neurodegenerative disorders. Many studies have demonstrated the association between the risk of neurodegenerative diseases and the antioxidative status, suggesting the importance of antioxidants as disease-preventing agents $[18,39,40,59]$. Oxidative stress is a factor acting in the early stage of neurodegeneration, raising the possibility that protection of macromolecules against free radical damage may have a beneficial effect [1]. Plant products are rich sources of phytochemicals that have been found to possess antioxidative properties. Recently, there has been an upsurge of interest in the therapeutic potential of medicinal plants as antioxidants in reducing free radical-induced injury. In this regard, some plant species that possess medicinal and antioxidant properties have been identified, e.g. Ginkgo biloba [42,50],
Panax ginseng [11,26], Thea sinensis [7,15], Scutellaria baicalensis [37,38] and Curcuma longa [22,44].

Huperzia selago (L.) Bernh. ex Schrank et Mart., a source of huperzine A (HupA) and other alkaloids commonly known as fir club moss (family Huperziaceae), is a plant of great interest that is used in combating a wide variety of diseases in European and Asian countries [30,32,48]. Plants of the species Diphasiastrum complanatum (L.) Holub (Lycopodiaceae) are rich in alkaloids, mostly lycopodine and its derivatives, generally biologically not yet investigated [30].

The Huperzia and Diphasiastrum alkaloids are of great importance due to their biological activity and unique chemical structures $[24,30]$. Various alkaloids derived from these plants and their therapeutic potentials have been characterized in several reports $[8,30,57,60]$. Pharmacological studies conducted since the 1980s have demonstrated that the therapeutic properties of Huperzia serrata, which has been used for centuries in traditional Chinese medicine, are due to the presence of many alkaloids, including HupA, which is a potent, reversible and selective acetylcholinesterase (AChE) inhibitor [30]. However, the neuroprotective action of these alkaloids goes beyond the inhibition of AChE. They may affect DNA synthesis, gene expression, mitochondrial function, oxidative stress, apoptosis and NGF signalling. Interestingly, HupA protects against liberation of amyloid beta peptides, which may be related to its beneficial effects on learning and memory deficiency in animal models and Alzheimer's disease patients $[8,30,57,60]$.

Studies on the pharmacological properties of HupA are being conducted in many centres worldwide, and a comprehensive review of them has been published by Zhang and Tang [60] and Ma et al. [32]. Moreover, studies by Szyputa et al. [46-48] have shown that $H$. selago is a rich source of HupA and other alkaloids, which are much more abundant in this plant than in the Chinese club moss $H$. serrata.

The aim of our study was to investigate and compare antioxidative properties of Huperzia selago and Diphasiastrum complanatum alkaloids in vitro. We analysed the effect of alkaloid extracts and HupA, lycopodine and annotinine authentic standards on protein oxidation and lipid peroxidation. Our results indicated for the first time that some components of $H$. selago alkaloid extract possess potent antioxidative properties, scavenge free radicals and prevent 
lipid and protein oxidation. These results indicated that $H$. selago might be a promising source of lead compounds for drug discovery.

\section{Material and methods Chemicals}

Dimethyl sulfoxide (DMSO), 2,2-diphenyl-1-picrylhydrazyl (DPPH), 2,4-dinitrophenylhydrazine, sodium hexafluorophosphate and acetonitrile were purchased from Sigma Chemical Co., St. Louis, MO, USA. Ferrous chloride tetrahydrate was from Fluka Chemie AG, Buchs, Switzerland; L-(+)-ascorbic acid was from Avocado Research Chemicals Ltd.; L-tyrosine, 2-thiobarbituric acid, hydrogen peroxide and water of HPLC grade were purchased from Merck KGaA, Darmstadt, Germany; chloroform, diethyl ether, ammonium and sodium chloride were from $\mathrm{POCH}$, Gliwice, Poland. All other common reagents were from Sigma-Aldrich (St. Louis, MO, USA). HupA was purchased from ChromaDex, Inc. (Laguna Hills, CA); the reference compounds lycopodine, alpha-obscurine and annotinine were obtained from the Department of Pharmacognosy and Molecular Basis of Phytotherapy, Medical University of Warsaw. For all standards at least ${ }^{1} \mathrm{H} N \mathrm{NMR},{ }^{13} \mathrm{C}$ NMR, 2D COSY, HMBC, UV- VIS and MS/MS spectra were recorded.

\section{Animals}

Male Wistar rats (200-250 g) were supplied by the Animal House of Mossakowski Medical Research Centre Polish Academy of Sciences, Warsaw, Poland. The animals $(n=5)$ were maintained at constant humidity, temperature and light cycle, and had free access to food and water. All experiments on animals were accepted by the Polish National Ethics Committee and were carried out in accordance with the European Communities Council Directive of 24 November 1986 (86/609/EEC).

\section{Preparation of rat brain cortex homogenate}

For analysis of protein and lipid oxidation, adult male Wistar rats were decapitated, their brains were removed, and brain cortices were isolated on ice and frozen at $-80^{\circ} \mathrm{C}$. Brain cortex was homogenized in ice-cold $50 \mathrm{mM}$ Tris- $\mathrm{HCl}$ buffer, pH 7.4, to obtain 10\% homogenate.

\section{Acquisition of plant material}

Aerial parts of $H$. selago were collected in the Babia Gora Biosphere Reserve (Poland) in September 2010. Aerial parts of $D$. complanatum were collected in the Masurian Lake District (Poland). A voucher collection permit of plants was obtained from the Ministry of Environment (Poland). Material was identified and authenticated by one of the authors (Wojciech Szypuła). Voucher specimens were deposited in the herbarium of the Department of Pharmaceutical Biology and Medicinal Plant Biotechnology, Medical University of Warsaw.

\section{Preparation and purification of extracts}

The extraction of alkaloids from $H$. selago was based on the protocol used by Wiedenfeld et al. [54] with modifications according to Szypula et al. [48]. A powdered plant sample of $H$. selago was accurately weighed $(190 \pm 0.01 \mathrm{~g})$ and placed in a 5 -L conical flask. Ultrasound extraction was carried out in an RK $100 \mathrm{H}$ ultrasonic cleaning bath (Bandelin Sonorex, Berlin, Germany), which had a mean operating frequency of $35 \mathrm{kHz}$, and the power was adjusted to $160 \mathrm{~W}$. The extraction was performed at $40^{\circ} \mathrm{C}$ for 30 min, each time with 2 I of methanol of analytical purity grade until the eluate was negative to Dragendorff's reagent. The extracts were decanted through fluted filter paper into a 2 I round-bottomed flask. The combined methanol extracts were evaporated to dryness under reduced pressure at $40^{\circ} \mathrm{C}$. The obtained residues were reconstituted into 1 I of $2.5 \%$ hydrochloric acid, transferred into a $2-1$ separator, and purified by extracting two times with 1 I of chloroform and once with 1 I of diethyl ether. The aqueous layer was adjusted to $\mathrm{pH} 9.0$ with $25 \%$ ammonia solution and then extracted with chloroform $(2 \times 1-1)$. Next, sodium chloride was gradually added to the aqueous layer until a saturated solution was obtained and it was again extracted with chloroform, until the eluate was negative to Dragendorff's reagent. The chloroform extracts were combined and evaporated to dryness under decreased pressure at $40^{\circ} \mathrm{C}$. The chloroformic extract was evaporated until dry in order to obtain $2.0 \mathrm{~g}$ of the crude total alkaloid extract $\mathrm{E}_{1}(\% \mathrm{w} / \mathrm{w}, 1.11 ; \% \mathrm{w} / \mathrm{w}$ calculated relative to dry starting material).

A dried $\mathrm{CHCl}_{3}$ extract $(2.0 \mathrm{~g})$ obtained from H. selago was chromatographed on Sephadex LH-20 in a glass column $(30 \times 2.5 \mathrm{~cm})$, eluting with mixtures 
of $\mathrm{CHCl}_{3}-\mathrm{MeOH}(100: 0 \rightarrow 70: 30 \mathrm{v} / \mathrm{v}$ in 16 steps $)$ as the mobile phase to give 129 fractions pooled into 7 main fractions containing alkaloids: AEF-1 (63.4 mg), AEF-2 (178.31 mg), AEF-3 (335.4 mg), AEF-4 (90.13 mg), AEF-5 (124.84 mg), AEF-6 (125.9 mg) and AEF-7 (77.1 mg).

The extraction of alkaloids from sporophytes of D. complanatum was performed using our own method. The air-dried whole plants of $D$. complanatum $(0.5 \mathrm{~kg})$ were extracted with $96 \% \mathrm{EtOH}$ twice. The extraction was performed at $25^{\circ} \mathrm{C}$ for $24 \mathrm{~h}$, each time with 3.5 I of ethanol of analytical purity grade until the eluate was negative to Dragendorff's reagent. The extracts were decanted through fluted filter paper into a 2 I round-bottomed flask. The combined ethanol extracts were evaporated to dryness under reduced pressure at $40^{\circ} \mathrm{C}$. The obtained residues were reconstituted into 0.7 I of $2 \%$ hydrochloric acid, transferred into a separator, and purified by extracting twice with benzene. Next, the aqueous layer was adjusted to $\mathrm{pH} 8.0$ with $25 \%$ ammonia solution and then extracted a few times with benzene and chloroform. The combined extracts were evaporated until dry in order to obtain $0.95 \mathrm{~g}$ of the crude total alkaloid extract (\% w/w, 0.19; \% w/w calculated relative to dry starting material). A dried combined extract $(0.95 \mathrm{~g})$ from $D$. complanatum was chromatographed on an aluminium oxide column (30 $\times 2.5 \mathrm{~cm})$, eluting with a mixture of $n$-hexane/benzene $(100: 0 \rightarrow 0: 100 \mathrm{v} / \mathrm{v}$ in 4 steps) to give $133 \mathrm{frac}$ tions pooled into 2 - AEF-8 (0.4 g) and AEF-9 (0.2 g) - main fractions. Fractions AEF-8-AEF-9 were purified by crystallization from acetone to give compounds AEF-8 (10 mg) and AEF-9 (5 mg). All AEF-1-AEF-7 and AEF-8-AEF-9 fractions were then submitted to TLC, HPLC-DAD and HPLC-ESI-MS/MS analysis.

\section{Thin layer chromatography (TLC) analysis of alkaloids}

The alkaloid extracts $(20 \mu \mathrm{g} / 20 \mu \mathrm{l})$ and $10 \mu \mathrm{l}$ of the separated (HupA, lycopodine, alpha-obscurine and annotinine) reference compounds in $1 \mathrm{ml}$ of $\mathrm{CHCl}_{3}$ were spotted on a silica gel plate (Merck Silica Gel 60F254, $10 \mathrm{~cm} \times 10 \mathrm{~cm})$. The mobile phase used was $\mathrm{CHCl}_{3}: \mathrm{MeOH}: \mathrm{NH}_{4} \mathrm{OH}(70: 7: 1, \mathrm{v}: \mathrm{v}: \mathrm{v})$. After chromatography the TLC plate was removed from the tank and air-dried. It was then sprayed with modified Dragendorff's reagent or $\mathrm{I}_{2}$ vapour. Huperzia and Diphasiastrum genus alkaloids showed up immediately as orange spots.

\section{High performance liquid chromatography with diode array detection (HPLC-DAD) and high performance liquid chromatography-electrospray tandem mass spectrometry (HPLC-ESI-MS/MS) of alkaloids}

Qualitative and quantitative HPLC-DAD analyses were performed on a Shimadzu system consisting of a UV-VIS and SPD-10A DAD 340 S detector, LC-10AD pump and LC solution software. A Hypersil GOLD column, $C_{18} 250 \times 4.6 \mathrm{~mm}$, and a Hypersil GOLD precolumn, 5 UM $10 \times 4 \mathrm{~mm}$, were used [48]. The mobile phase consisted of $(A)$ water with the addition of $30 \mathrm{mM} \mathrm{NaPF}_{6}$ and (B) acetonitrile. The following gradient was applied: 0-5 min $0 \rightarrow 25 \%$ B, 5-20 min $25 \rightarrow 45 \%$ B, 20-30 min $45 \rightarrow 80 \%$ B [48]. Column temperature: $24 \pm 1^{\circ} \mathrm{C}$, flow rate of the mobile phase: $1.0 \mathrm{ml} / \mathrm{min}$, analysis duration: $30 \mathrm{~min}$, detection at wavelengths $\lambda=210,230,260,310 \mathrm{~nm}$.

Individual alkaloids were identified by the HPLCESI-MS/MS method. The measurements were carried out on a High-Performance Liquid Chromatograph Prominence LC-20 (Shimadzu) coupled with a 4000 QTrap mass spectrometer. The LC separation was performed on a Hydro RP C18 column (Phenomenex) using as a mobile phase $10 \mathrm{mM} \mathrm{CH}_{3} \mathrm{COONH}_{4}$ aqueous solution with $\mathrm{HCOOH}$ addition to obtain $\mathrm{pH} 4.3$ (A) and $\mathrm{MeCN}(\mathrm{B})$, in the following linear gradient: $0-5 \min 30 \rightarrow 45 \%$ B, $5-40$ min $45 \rightarrow 95 \%$ B. Column temperature: $24 \pm 1^{\circ} \mathrm{C}$, flow rate of the mobile phase: $1.0 \mathrm{ml} / \mathrm{min}$. The analysis was performed at $230 \mathrm{~nm}$ and $270 \mathrm{~nm}$.

The electrospray ionisation mass spectrometry (ESI-MS) spectra were recorded in the positive ion mode, in the $\mathrm{m} / \mathrm{z}$ range $100-1000$. The source parameters set was as follows: IS $5500 \mathrm{~V}, \mathrm{DP} 40 \mathrm{~V}$, EP $10 \mathrm{~V}$ and the source temperature was $550^{\circ} \mathrm{C}$.

The fragmentation spectra were performed also in the positive ion mode. The collision energy was optimized to obtain the most informative CID (collision-induced dissociation) spectra of investigated compounds.

\section{Preparation of standard solution and sample solution}

Standard solutions of HupA, lycopodine, alphaobscurine and annotinine were prepared by weighing into an Eppendorf tube approximately $1 \pm 0.1 \mathrm{mg}$ of the standard substance, and a sample solution 
was obtained by dissolving the alkaloid fraction isolated from the plant material in methanol of HPLC purity grade to a concentration of $1 \mathrm{mg} / \mathrm{ml}$. Approximately $1 \pm 0.1 \mathrm{mg}$ was weighed using an analytical balance into Eppendorf tubes and reconstituted in methanol of HPLC purity grade to obtain a solution of $1 \mathrm{mg}$ of extract in $1 \mathrm{ml}$ of methanol. Aliquots of $20 \mu \mathrm{l}$ of the solution were introduced into the column. To obtain the fragmentation spectra of HupA, lycopodine, alpha-obscurine and annotinine standard, the methanol extracts were injected directly into the electrospray interface of the mass spectrometer in positive ion mode ESI(+). To obtain the fragmentation spectra of HupA and other alkaloids from the plant material, appropriate solutions of the fraction $(10 \mu \mathrm{l}$ of the fraction solution corresponding to $10 \mu \mathrm{g}$ of the fraction) were introduced into the chromatographic column. For all compounds at least UV-VIS and MS/MS spectra were recorded. Data obtained from all experiments (retention factor and retention time, UV spectrum, total ion chromatogram, selected ion chromatograms for specific $\mathrm{m} / \mathrm{z}$ and comparison of the fragmentation quasi-molecular ion of the standards and the ion with $\mathrm{m} / \mathrm{z}$ corresponding to the appropriate alkaloids in plant material) were compared with those reported in the literature (see Table I) and, if standards were available, comparison was made by HPLC-ESI-MS/MS method.

\section{Preparation of alkaloid extracts (AEF) for biochemical studies}

Samples were dissolved in DMSO at a concentration of $25 \mathrm{mg} / \mathrm{ml}$, which roughly corresponds to molar concentration approximately $100 \mathrm{mM}$ for this group of alkaloids. Then dilutions were prepared in the same DMSO concentration, and AEF were used in final concentrations of $0.25 \mu \mathrm{g} / \mathrm{ml}$ (approximately $1 \mu \mathrm{M}$ ), $2.5 \mu \mathrm{g} / \mathrm{ml}$ (approximately $10 \mu \mathrm{M}$ ) and 6.25 $\mu \mathrm{g} / \mathrm{ml}$ (approximately $25 \mu \mathrm{M}$ ).

\section{Determination of the antioxidant activity of AEF}

The free radical scavenging properties of AEF were determined by analysis of the 2,2-diphenyl-1-picrylhydrazyl (DPPH) radical scavenging activity following the method reported by Blois [9] with some modifications [12]. The tested AEF $(0-25 \mu \mathrm{g} / \mathrm{ml})$ was mixed with $1 \mathrm{M}$ Tris- $\mathrm{HCl}$ buffer ( $\mathrm{pH}$ 7.9) and $50 \mu \mathrm{M}$ solution of DPPH in methanol. The samples were incubated for $20 \mathrm{~min}$ at room temperature in the dark, and then the absorbance at $517 \mathrm{~nm}$ was determined on a Model 680 Microplate Reader (Bio-Rad). Samples with appropriate concentration of DMSO instead of AEF were used as the control, and samples without DPPH were used as blanks.

\section{Determination of the effect of AEF on dityrosine formation}

The effect of AEF on dityrosine formation was determined in a protein-free system according to the method described by Ferdinandy and Schulz [16] with some modifications [13]. L-tyrosine $(0.5 \mathrm{mM})$ was incubated with $\mathrm{CuSO}_{4}(100 \mu \mathrm{M})$ and $\mathrm{H}_{2} \mathrm{O}_{2}(100 \mathrm{mM})$ in the presence of AEF $(2.5 \mu \mathrm{g} / \mathrm{ml})$ for $10 \mathrm{~min}$ at room temperature. The fluorescence of formed dityrosine was determined spectrofluorimetrically at $325 \mathrm{~nm}$ excitation and $405 \mathrm{~nm}$ emission.

\section{Determination of the effect of AEF on lipid peroxidation}

The effect of AEF on lipid peroxidation was determined in the rat brain cortex homogenate incubated with $\mathrm{FeCl}_{2}$ and ascorbic acid, as an ROS-generating system. The $10 \%$ homogenate was incubated with $25 \mu \mathrm{M} \mathrm{FeCl}$ and $10 \mu \mathrm{M}$ ascorbic acid in the presence of $\operatorname{AEF}(25 \mu \mathrm{g} / \mathrm{ml})$ for $15 \mathrm{~min}$ at $37^{\circ} \mathrm{C}$ in a final volume of $0.2 \mathrm{ml}$. The level of thiobarbituric acid reactive substances (TBARS) was determined as an index of lipid peroxidation according to the method reported by Asakawa and Matsushita [2] with some modifications [14].

\section{Determination of the effect of AEF on carbonyl group formation}

The effect of AEF on protein oxidation was determined in the rat brain cortex homogenate incubated with $\mathrm{FeCl}_{2}$ and ascorbic acid, as an ROS-generating system. Protein oxidation was analysed by determining the content of the carbonyl groups. The $10 \%$ homogenate was incubated with $25 \mu \mathrm{M} \mathrm{FeCl}_{2}$ and $10 \mu \mathrm{M}$ ascorbic acid in the presence of AEF $(25 \mu \mathrm{g} /$ $\mathrm{ml}$ ) for $15 \mathrm{~min}$ at $37^{\circ} \mathrm{C}$ in a final volume of $0.2 \mathrm{ml}$. The carbonyl group concentration was determined by derivatization with dinitrophenylhydrazine (DNPH) according to the method described by Oliver et al. [35] with some modifications [14]. 
Table I. Composition of alkaloid fractions of Huperzia selago (L.) Bernh. ex Schrank et Mart. and Diphasiastrum complanatum (L.) Holub. The table shows formulas, and theoretical and empirical molecular masses of possible components for each fraction. AEF-1-AEF-7 refer to the alkaloids isolated from $\mathrm{H}$. selago, and AEF-8 and AEF-9 are from D. complanatum

\begin{tabular}{|c|c|c|c|c|c|}
\hline \multicolumn{2}{|c|}{$\begin{array}{l}\text { Fraction } \\
\text { and compound } \\
\text { number }\end{array}$} & \multirow{2}{*}{$\begin{array}{l}\text { Formula } \\
\mathrm{C}_{17} \mathrm{H}_{26} \mathrm{~N}_{2} \mathrm{O}\end{array}$} & \multirow{2}{*}{$\begin{array}{c}{\left[\begin{array}{c}{[\mathrm{M}+\mathrm{H}]^{+}} \\
(\mathrm{m} / \mathrm{z},\end{array}\right.} \\
\text { theoretical } \\
\text { mass })\end{array}$} & \multirow{2}{*}{$\begin{array}{c}\text { (+)-ESIMS } \\
(\mathrm{m} / \mathrm{z} \text {, from } \\
\text { spectrum) }\end{array}$} & \multirow{2}{*}{$\begin{array}{l}\text { Identification or possible alkaloid } \\
\text { curine, confirmed using TLC, HPLC-DAD and ESI-MS } \\
\text { method in the present study }\end{array}$} \\
\hline$A E F-1$ & 1 & & & & \\
\hline & 2 & $\mathrm{C}_{17} \mathrm{H}_{30} \mathrm{~N}_{2}$ & 263.2482 & 263.3 & Nankakurine A $[23,24]$ \\
\hline & 3 & $\mathrm{C}_{16} \mathrm{H}_{23} \mathrm{NO}_{2}$ & 262.1801 & 262.3 & $\begin{array}{l}\text { Acrifoline, confirmed using TLC, HPLC-DAD and ESI-MS method in } \\
\text { the present study and literature data according to }[20,30]\end{array}$ \\
\hline & 4 & $\mathrm{C}_{16} \mathrm{H}_{22} \mathrm{~N}$ & 258.1734 & 257.1 & Des- $N$-methyl- $\beta$-obscurine $[3,31]$ \\
\hline & 5 & $\mathrm{C}_{17} \mathrm{H}_{22} \mathrm{~N}_{2} \mathrm{O}_{2}$ & 287.1754 & 287.1 & Huperzine D [24] \\
\hline & 6 & $\mathrm{C}_{16} \mathrm{H}_{21} \mathrm{~N}_{2} \mathrm{O}$ & 257.1659 & 257.1 & Lyconadin A [27] \\
\hline & 7 & $\mathrm{C}_{16} \mathrm{H}_{25} \mathrm{NO}_{2}$ & 264.3752 & 264.3 & Lycodoline [21] \\
\hline \multirow[t]{7}{*}{$A E F-2$} & 1 & $\mathrm{C}_{16} \mathrm{H}_{20} \mathrm{~N}_{2} \mathrm{O}$ & 257.1648 & 257.1 & $\begin{array}{l}\text { Huperzine B - confirmed using TLC, HPLC-DAD and ESI-MS meth- } \\
\text { od in the present study and literature data according to [24] }\end{array}$ \\
\hline & 2 & $\mathrm{C}_{16} \mathrm{H}_{22} \mathrm{~N}$ & 258.1734 & 257.1 & Des- $N$-methyl- $\beta$-obscurine $[3,31]$ \\
\hline & 3 & $\mathrm{C}_{16} \mathrm{H}_{23} \mathrm{~N}_{2}$ & 243.1861 & 243.1 & Lycodine $[30,58]$ \\
\hline & 4 & $\mathrm{C}_{16} \mathrm{H}_{25} \mathrm{NO}$ & 248.2009 & 248.3 & $\begin{array}{l}\text { Lycopodine confirmed using TLC, HPLC-DAD and ESI-MS method } \\
\text { in the present study and literature data according to [24] }\end{array}$ \\
\hline & 5 & $\mathrm{C}_{16} \mathrm{H}_{24} \mathrm{NO}$ & 246.1852 & 246.1 & Fawcettidine [29] \\
\hline & 6 & $\mathrm{C}_{16} \mathrm{H}_{25} \mathrm{NO}_{2}$ & $\begin{array}{c}264.1968 \text { or } \\
264.1969\end{array}$ & 264.2 & Lycoposerramine-L or lycoposerramine-M [49] \\
\hline & 7 & $\mathrm{C}_{16} \mathrm{H}_{23} \mathrm{NO}_{2}$ & 262.1801 & 262.1 & $\begin{array}{l}\text { Acrifoline confirmed using TLC, HPLC-DAD and ESI-MS method in } \\
\text { the present study and literature data according to [20] }\end{array}$ \\
\hline \multirow[t]{7}{*}{ AEF-3 } & 1 & $\mathrm{C}_{15} \mathrm{H}_{18} \mathrm{~N}_{2} \mathrm{O}$ & 243.1492 & 243.1 & $\begin{array}{l}\text { Huperzine A - confirmed using TLC, HPLC-DAD and ESI-MS meth- } \\
\text { od in the present study and literature data according to [48] }\end{array}$ \\
\hline & 2 & $\mathrm{C}_{16} \mathrm{H}_{25} \mathrm{NO}_{3}$ & 280.1893 & 280.1 & Lycoposerramine-G or serratezamine C [45] \\
\hline & 3 & $\mathrm{C}_{16} \mathrm{H}_{25} \mathrm{NO}$ & 248.2009 & 248.3 & $\begin{array}{l}\text { Lycopodine confirmed using TLC, HPLC-DAD and ESI-MS method } \\
\text { in the present study }\end{array}$ \\
\hline & 4 & $\mathrm{C}_{16} \mathrm{H}_{26} \mathrm{NO}_{2}$ & 264.3620 & 264.3 & $\begin{array}{l}\text { 6-Hydroxylycopodine (flabelliformine) confirmed using ESI-MS } \\
\text { method in the present study }\end{array}$ \\
\hline & 5 & $\mathrm{C}_{16} \mathrm{H}_{20} \mathrm{~N}_{2} \mathrm{O}$ & 257.1648 & 257.1 & $\begin{array}{l}\text { Huperzine B confirmed using TLC, HPLC-DAD and ESI-MS method } \\
\text { in the present study and literature data according to [24] }\end{array}$ \\
\hline & 6 & $\mathrm{C}_{15} \mathrm{H}_{18} \mathrm{~N}_{2} \mathrm{O}$ & 259.1369 & 259.1 & 6- $\beta$-Hydroxyhuperzine $[5,55]$ \\
\hline & 7 & $\mathrm{C}_{16} \mathrm{H}_{25} \mathrm{NO}_{2}$ & $\begin{array}{c}264.1968 \text { or } \\
264.1969\end{array}$ & 264.2 & Lycoposerramine-L or lycoposerramine-M [49] \\
\hline \multirow[t]{8}{*}{ AEF-4 } & 1 & $\mathrm{C}_{15} \mathrm{H}_{18} \mathrm{~N}_{2} \mathrm{O}_{2}$ & 259.3156 & 259.3 & 6- $\beta$-Hydroxyhuperzine $[5,55]$ \\
\hline & & $\mathrm{C}_{15} \mathrm{H}_{18} \mathrm{~N}_{2} \mathrm{O}$ & 243.1492 & 243.1 & $\begin{array}{l}\text { Huperzine A confirmed using TLC, HPLC-DAD and ESI-MS method } \\
\text { in the present study and literature data according to [48] }\end{array}$ \\
\hline & 2 & $\mathrm{C}_{16} \mathrm{H}_{25} \mathrm{NO}_{2}$ & $\begin{array}{l}264.1968 \text { or } \\
264.1969\end{array}$ & 264.2 & Lycoposerramine-L or lycoposerramine-M [49] \\
\hline & 3 & $\mathrm{C}_{16} \mathrm{H}_{25} \mathrm{NO}$ & 248.2009 & 248.1 & $\begin{array}{l}\text { Lycopodine confirmed using TLC, HPLC-DAD and ESI-MS method } \\
\text { in the present study and literature data according to [24] }\end{array}$ \\
\hline & 4 & $\mathrm{C}_{16} \mathrm{H}_{25} \mathrm{NO}_{3}$ & 280.1893 & 280.1 & Lycoposerramine-G [49] \\
\hline & 5 & $\mathrm{C}_{16} \mathrm{H}_{20} \mathrm{~N}_{2} \mathrm{O}$ & 257.1648 & 257.1 & $\begin{array}{l}\text { Huperzine B confirmed using TLC, HPLC-DAD and ESI-MS method } \\
\text { in the present study and literature data according to [24] }\end{array}$ \\
\hline & 6 & $\mathrm{C}_{16} \mathrm{H}_{24} \mathrm{NO}_{3}$ & 278.1754 & 278.1 & Probably 8b-hydroxylycoposerramine K [53] \\
\hline & 7 & $\mathrm{C}_{16} \mathrm{H}_{23} \mathrm{~N}_{2} \mathrm{O}$ & 259.1805 & 259.1 & Lyconadin E [25] \\
\hline
\end{tabular}


Table I. Continue

\begin{tabular}{|c|c|c|c|c|c|}
\hline \multicolumn{2}{|c|}{$\begin{array}{l}\text { Fraction } \\
\text { and compound } \\
\text { number }\end{array}$} & Formula & $\begin{array}{c}{[\mathrm{M}+\mathrm{H}]^{+}} \\
(\mathrm{m} / \mathrm{z}, \\
\text { theoretical } \\
\text { mass })\end{array}$ & $\begin{array}{l}(+) \text {-ESIMS } \\
(\mathrm{m} / \mathrm{z}, \text { from } \\
\text { spectrum })\end{array}$ & Identification or possible alkaloid \\
\hline \multirow[t]{4}{*}{ AEF-5 } & 1 & $\mathrm{C}_{16} \mathrm{H}_{25} \mathrm{NO}$ & 248.2009 & 248.3 & $\begin{array}{l}\text { Lycopodine confirmed using TLC, HPLC-DAD and ESI-MS method } \\
\text { in the present study and literature data according to [24] }\end{array}$ \\
\hline & 2 & $\mathrm{C}_{16} \mathrm{H}_{24} \mathrm{NO}_{2}$ & 262.1803 & 262.1 & Serratidine [45] \\
\hline & 3 & $\mathrm{C}_{16} \mathrm{H}_{25} \mathrm{NO}_{3}$ & 280.1893 & 280.1 & Lycoposerramine-G [49] \\
\hline & 4 & $\mathrm{C}_{17} \mathrm{H}_{32} \mathrm{~N}_{2}$ & 265.3108 & 265.3 & Probably cermizine B [33] \\
\hline \multirow[t]{6}{*}{ AEF-6 } & 1 & $\mathrm{C}_{16} \mathrm{H}_{27} \mathrm{NO}$ & 250.3920 & 250.3 & $\begin{array}{l}\text { Dihydrolycopodine confirmed using TLC, HPLC-DAD and ESI-MS } \\
\text { method in the present study and literature data according to [19] }\end{array}$ \\
\hline & 2 & $\mathrm{C}_{16} \mathrm{H}_{25} \mathrm{NO}_{2}$ & $\begin{array}{l}264.1968 \text { or } \\
264.1969\end{array}$ & 264.2 & Lycoposerramine-L or lycoposerramine-M [49] or flabelliformine \\
\hline & 3 & $\mathrm{C}_{16} \mathrm{H}_{25} \mathrm{NO}$ & 248.2009 & 248.3 & $\begin{array}{l}\text { Lycopodine confirmed using TLC, HPLC-DAD and ESI-MS method } \\
\text { in the present study and literature data according to [24] }\end{array}$ \\
\hline & 4 & $\mathrm{C}_{16} \mathrm{H}_{24} \mathrm{NO}_{2}$ & 262.1803 & 262.1 & Serratidine [45] \\
\hline & 5 & $\mathrm{C}_{16} \mathrm{H}_{25} \mathrm{NO}_{3}$ & 280.1893 & 280.1 & Lycoposerramine-G or serratezamine C [45] \\
\hline & 6 & $\mathrm{C}_{16} \mathrm{H}_{24} \mathrm{NO}$ & 246.1852 & 246.1 & Fawcettidine [36] \\
\hline \multirow[t]{2}{*}{ AEF-7 } & 1 & $\mathrm{C}_{16} \mathrm{H}_{27} \mathrm{NO}$ & 250.3920 & 250.3 & $\begin{array}{l}\text { Dihydrolycopodine - confirmed using TLC, HPLC-DAD and ESI-MS } \\
\text { method in the present study and literature data according to [19] }\end{array}$ \\
\hline & 2 & $\mathrm{C}_{16} \mathrm{H}_{24} \mathrm{NO}$ & 246.1852 & 246.1 & Fawcettidine [36] \\
\hline AEF-8 & 1 & $\mathrm{C}_{16} \mathrm{H}_{25} \mathrm{NO}$ & 248.2009 & 248.3 & $\begin{array}{l}\text { Lycopodine confirmed using TLC, HPLC-DAD and ESI-MS method } \\
\text { in the present study and literature data according to [24] }\end{array}$ \\
\hline \multirow[t]{3}{*}{ AEF-9 } & 1 & $\mathrm{C}_{16} \mathrm{H}_{25} \mathrm{NO}$ & 248.2009 & 248.3 & $\begin{array}{l}\text { Lycopodine confirmed using TLC, HPLC-DAD and ESI-MS method } \\
\text { in the present study and literature data according to [24] }\end{array}$ \\
\hline & 2 & $\mathrm{C}_{16} \mathrm{H}_{24} \mathrm{NO}$ & 246.1852 & 246.1 & Fawcettidine [36] \\
\hline & 3 & $\mathrm{C}_{16} \mathrm{H}_{27} \mathrm{NO}$ & 250.3920 & 250.3 & Dihydrolycopodine \\
\hline \multicolumn{2}{|l|}{10} & $\mathrm{C}_{16} \mathrm{H}_{21} \mathrm{NO}_{3}$ & 276.3428 & 276.4 & Annotinine authentic standard \\
\hline \multicolumn{2}{|l|}{11} & $\mathrm{C}_{16} \mathrm{H}_{25} \mathrm{NO}$ & 248.2009 & 248.3 & Lycopodine authentic standard \\
\hline \multicolumn{2}{|l|}{12} & $\mathrm{C}_{15} \mathrm{H}_{18} \mathrm{~N}_{2} \mathrm{O}$ & 243.1492 & 243.1 & Huperzine A authentic standard \\
\hline
\end{tabular}

\section{Statistics}

Statistical analysis was performed with Graph Pad Prism version 6.0 (GraphPad Software, San Diego, CA) using one-way analysis of variance (ANOVA) with the Newman-Keuls post-hoc test. Data are presented as means \pm SEM. $P<0.05$ was considered significant.

\section{Results}

In the present study to determine the content of alkaloids in $H$. selago and $D$. complanatum plants, dry alkaloid extracts were separated using column chromatography and were analysed using several methods. The results indicated that they contain numerous different types of alkaloids, pre- viously classified by Ayer and Trifonow [4] into four structural classes: the lycopodine class, the lycodine class, the fawcettimine class and the miscellaneous group (Table I). The antioxidant activities of alkaloid fractions (AEF) in the cell-free system were assessed by measuring their capabilities for scavenging 2,2-diphenyl-1-picrylhydrazyl (DPPH) and via the analysis of their effect on dityrosine formation, that is a biomarker of oxidative stress in biological samples. Moreover, antioxidative properties of these compounds were analysed using rat brain cortex homogenate. Oxidative stress in the homogenate was evoked by Fenton's reaction generating the hydroxyl radical in the presence of $\mathrm{FeCl}_{2}$ and ascorbic acid (Fe/Asc). The antiradical activity of all AEF examined by free radical DPPH scavenging tests 
A

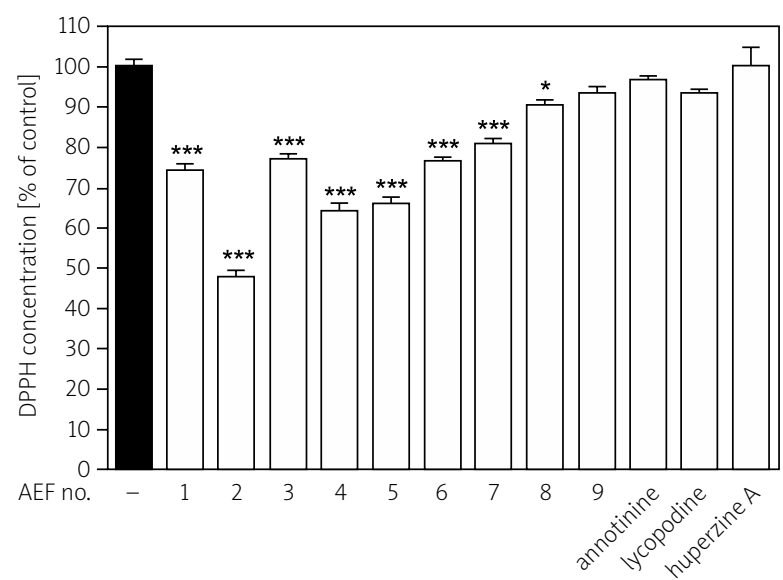

C

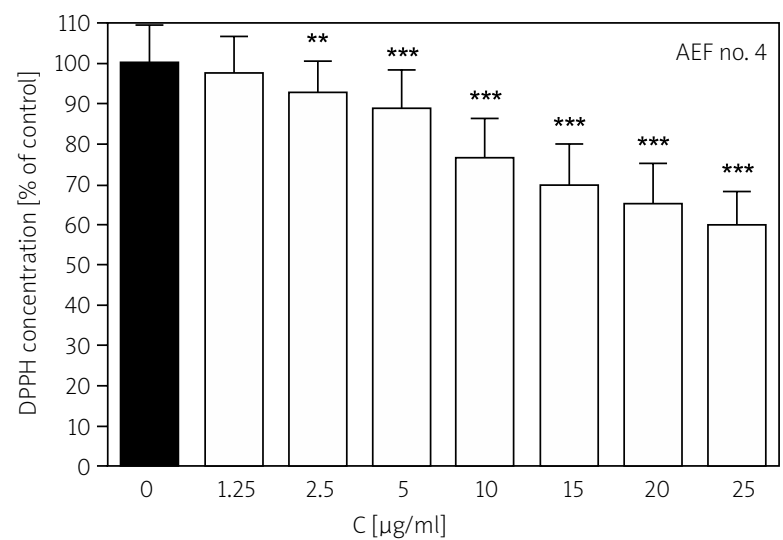

B

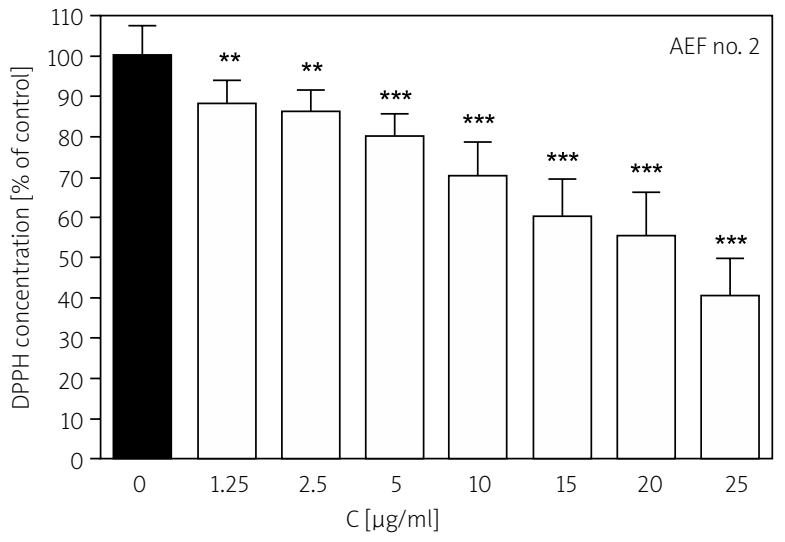

D

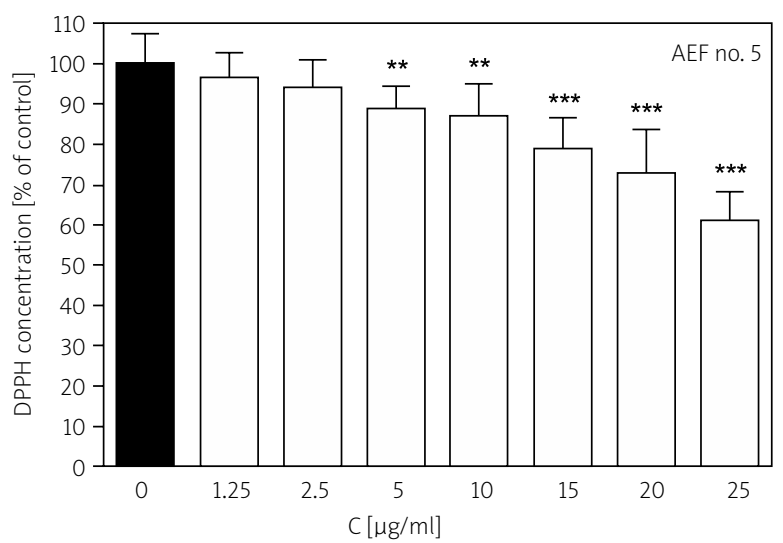

Fig. 1. Free radical scavenging properties of alkaloid fractions (AEF). The direct free radical scavenging properties of tested alkaloids were determined using the DPPH assay. A) The stable free radical DPPH was incubated for $20 \mathrm{~min}$ at room temperature in the presence of the tested AEF at $25 \mu \mathrm{g} / \mathrm{ml}$, and then the concentration of DPPH was determined spectrophotometrically. B-D) The most powerful free radical scavengers were tested in the concentration range $0-25 \mu \mathrm{g} / \mathrm{ml}$. Each chart represents a separate set of experiments. All values are the means \pm SEM from three experiments. ${ }^{*},{ }^{* \star},{ }^{* *} p<0.05,0.01$ and 0.001 , respectively, compared to the control.

demonstrated that AEF $1-8$ at $25 \mu \mathrm{g} / \mathrm{ml}$ were capable of scavenging the DPPH radical (Fig. 1A). The most potent antioxidants, AEF-2, -4 and -5 , were tested in the concentration range $0-25 \mu \mathrm{g} / \mathrm{ml}$. As shown in Figure 1B-D, all these AEF scavenged the DPPH free radical in a concentration-dependent manner. The most powerful free radical scavenger was AEF-2, which affected the level of DPPH at a concentration of $1.25 \mu \mathrm{g} / \mathrm{ml}(\mathrm{IC} 50=21.9 \mu \mathrm{g} / \mathrm{ml})$. AEF-4 and -5 were less efficient scavengers of the DPPH radical (IC50 $>25 \mu \mathrm{g} / \mathrm{ml})$. These results indicated that selected AEF show proton-donating ability and could serve as free radical scavengers, acting possibly as primary antioxidants. Since the formation of dityrosine in a protein exposed to oxygen free radicals can serve as a marker of oxidative stress, we analysed the effect of all AEF on dityrosine level in the protein-free reaction in which oxidative stress was evoked by Fenton's reaction. Oxidation of L-tyrosine leads to formation of a tyrosyl radical that dimerizes to form dityrosine. As demonstrated in Figure 2, AEF-1, -4 and -5 caused a significant delay in formation of dityrosine evoked by CuSO ${ }_{4}$, and $\mathrm{H}_{2} \mathrm{O}_{2}, \mathrm{AEF}-3,-6,-7$ and lycopodine also subtly attenuated dityrosine formation. Other alkaloids had no effect. Lipid peroxidation involves the formation and propagation of lipid radicals with numerous deleterious effects, including destruction of membrane lipids, and production of malondialdehyde and other thiobarbituric acid-reactive substances (TBARS). The thiobarbituric 

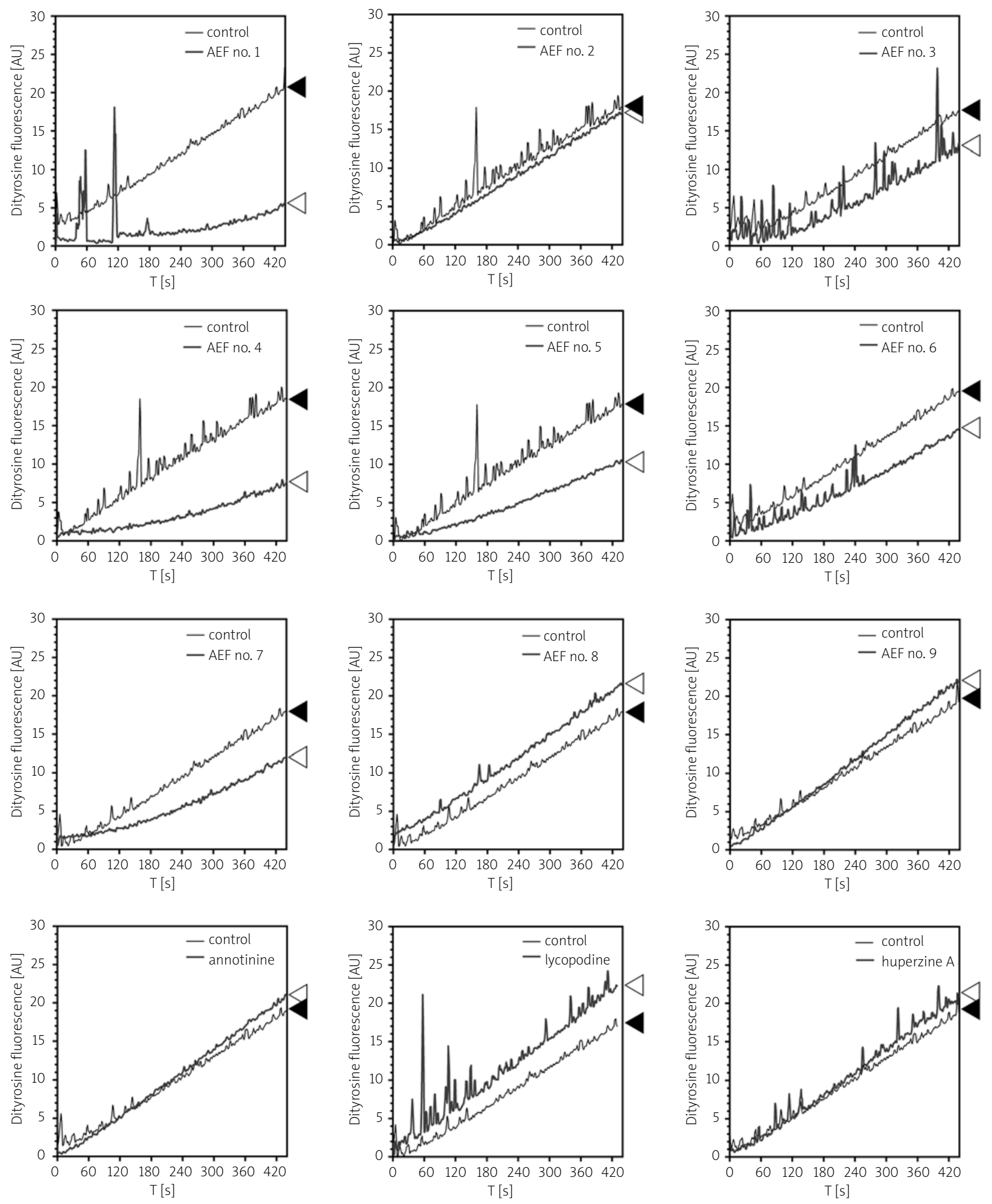

Fig. 2. The effect of alkaloid fractions (AEF) on dityrosine formation. L-tyrosine $(0.5 \mathrm{mM})$ was incubated in PBS at room temperature in the absence (control $\varangle$ ) and in the presence $(\triangleleft)$ of tested alkaloids with gentle mixing. Oxidative stress was induced by $\mathrm{CuSO}_{4}$ and $\mathrm{H}_{2} \mathrm{O}_{2}$. AEF were in a concentration of $2.5 \mu \mathrm{g} / \mathrm{ml}$. Dityrosine concentration was determined by measurement of fluorescence (Ex, $325 \mathrm{~nm}$; Em, $405 \mathrm{~nm}$ ). 
acid-reactive substances assay was used to measure formation of lipid peroxides in rat brain cortex homogenate, as a lipid-rich structure. Incubation of rat brain homogenate in the presence of Fe/Asc evoked a rapid increase in the level of lipid peroxidation (Fig. 3). AEF-2 and -4 used at a concentration of $25 \mu \mathrm{g} / \mathrm{ml}$ significantly reduced the level of Fe/Ascevoked lipid peroxidation by ca. 20\%. Other tested AEF had no effect on the level of TBARS (Fig. 3). In addition, AEF-5 reduced the level of Fe/Asc-induced protein oxidation by ca. $76 \%$, and AEF-4 showed a strong tendency, leading to an approximately $52 \%$ decrease (Fig. 4). Therefore, these data indicate that selected alkaloids contributed significantly to the inhibition of lipid and protein oxidation.

\section{Discussion}

Oxidative stress is an extensive cellular process responsible for unspecific modification of macromolecules leading to impairment of major metabolic pathways [41]. Approaches to prevent oxidative damage usually involve enhancing antioxidant defence with nutritional supplements or vitamins. Although

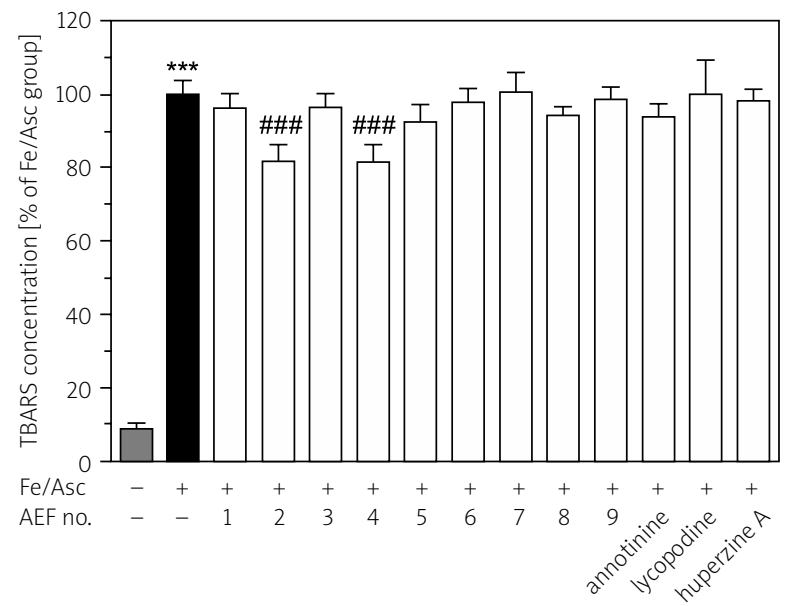

Fig. 3. The effect of alkaloid fractions (AEF) on lipid peroxidation in rat brain homogenate. The homogenate was incubated for $15 \mathrm{~min}$ at $37^{\circ} \mathrm{C}$ in the presence of $\mathrm{FeCl}_{2}(25 \mu \mathrm{M})$, ascorbic acid $(10 \mu \mathrm{M})$ and the tested alkaloids at a concentration of $25 \mu \mathrm{g} / \mathrm{ml}$. Lipid peroxidation was determined by measuring thiobarbituric acid reactive substances (TBARS). All values are the means \pm SEM from 4-5 experiments carried out in triplicate. Statistical significance ${ }^{* *} p<0.001$, compared to untreated control. ${ }^{\# \#} p<0.001$, compared to the Fe/Asc-treated group. various antioxidative compounds have been tested in clinical studies, there is still a need for effective therapies against oxidative stress. The growing body of evidence approves the importance of natural products as lead compounds in drug discovery.

Pharmacological properties of alkaloids isolated from club moss have been described previously [6]. Cytoprotective properties of club moss extracts were suggested in neurodegenerative processes via their antioxidant and anti-inflammatory properties. Moreover, it was indicated that alkaloid extracts from Lycopodium species inhibited acetylcholinesterase (AChE) activity in rat brain [28]. HupA is reported to increase efficiency of learning and memory in animals, and it was shown to be a promising treatment of Alzheimer's disease. About 201 Lycopodium alkaloids from 54 species of $L$. sensu lato (including the genera Huperzia and Diphasiastrum) have been reported so far [30]. In the present study it was demonstrated that selected alkaloid fractions from Huperzia selago possess some antioxidative potential. AEF-2, -4 and -5 seem to be the most promising sources of antioxidative compounds.

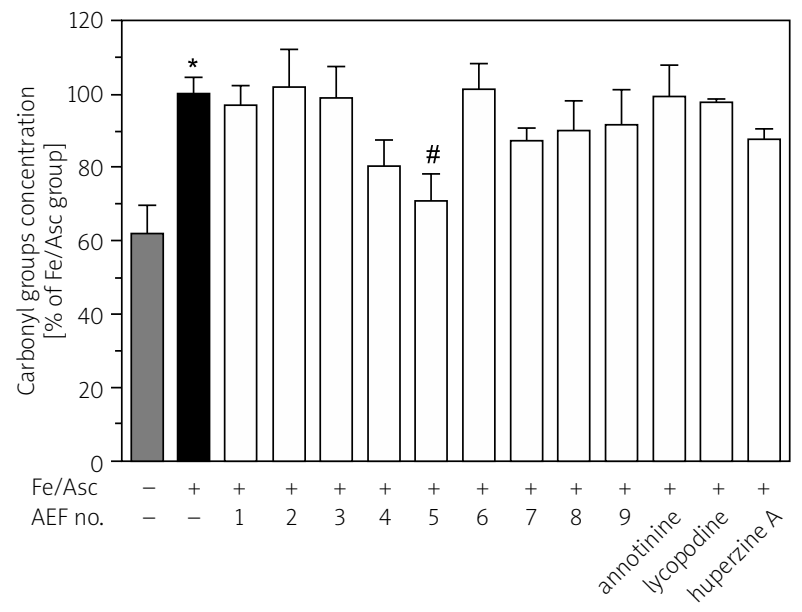

Fig. 4. The effect of alkaloid fractions (AEF) on protein oxidation in rat brain homogenate. The homogenate was incubated for $15 \mathrm{~min}$ at $37^{\circ} \mathrm{C}$ in the presence of $\mathrm{FeCl}_{2}(25 \mu \mathrm{M})$, ascorbic acid $(10 \mu \mathrm{M})$ and the tested AEF at a concentration of $25 \mu \mathrm{g} / \mathrm{ml}$. The level of carbonyl groups was determined as described in Material and Methods. All values are the means \pm SEM from 3-4 experiments carried out in triplicate. Statistical significance: ${ }^{*} p<0.05$, compared to the untreated control. ${ }^{\#} p<0.05$, compared to the Fe/Asc-treated group. 
AEF-2 potently reduced the level of lipid peroxidation, but had no effect on the level of carbonyl groups and on dityrosine formation. AEF-2 very efficiently scavenged DPPH radicals in a concentration $\geq 1.25 \mu \mathrm{g} / \mathrm{ml}$. The identified components of this fraction were huperzine $B$, des- $N$-methyl- $\beta$-obscurine, lycodine, lycopodine, fawcettidine, lycoposerramine- $\mathrm{L}$ or lycoposerramine- $M$ and acrifoline (Table I). AEF-4 at a concentration of $25 \mu \mathrm{g} / \mathrm{ml}$ effectively reduced the level of lipid peroxidation and showed some tendency to reduce the level of carbonyl groups. It scavenged DPPH radicals at concentrations $\geq 2.5 \mu \mathrm{g} / \mathrm{ml}$ and significantly inhibited the rate of dityrosine formation. The identified components of this fraction were 6 - $\beta$-hydroxyhuperzine, huperzine $A$, huperzine $B$, lycoposerramine- $L$ or lycoposerramine- $M$, lycopodine, lycoposerramine-G, probably 8b-hydroxylycoposerramine $\mathrm{K}$ and lyconadin (Table I). AEF-5 significantly reduced the level of carbonyl groups and scavenged DPPH radicals at concentration $\geq 5 \mu \mathrm{g} / \mathrm{ml}$. It also reduced the rate of dityrosine formation. The identified components of this fraction were lycopodine, serratidine, lycoposerramine-G and probably cermizine $B$ (Table I).

Our study demonstrated that fractions AEF-2, -4 and -5 contain alkaloids which may possess potent and direct antioxidative activity. Analysis of components of tested fractions (Table I) revealed that lycodine, lycoposerramine-G, 8b-hydroxylycoposerramine $\mathrm{K}$ and cermizine $\mathrm{B}$ are exclusively present in AEF-2, -4 and -5 , but not in other fractions; thus they might be responsible for the antioxidative properties of these fractions. Antioxidative potential of these compounds has not been studied before. Our data indicated that direct scavenging of free radicals may be a major way of antioxidative actions of AEF-2, -4 and -5 , although some indirect effects cannot be excluded. Additional studies are necessary to reveal which components are responsible for antioxidative properties of the selected fractions, and to determine the exact mechanism of their antioxidative activity. It was previously suggested that HupA possesses potent antiapoptotic, neuroprotective and antioxidative properties $[34,43,51,52,56]$. Our study demonstrated that this alkaloid is not a direct scavenger of free radicals, and other mechanisms are responsible for its antioxidative potential. Further studies should reveal whether protection of mitochondrial function, stimulation of antioxidative enzymes or non-enzy- matic defence may also be involved in antioxidative action of HupA as well as of AEF-2, -4 and -5 .

Our results indicated for the first time that alkaloid extracts from $H$. selago possess antioxidative properties, scavenge free radicals and prevent lipid and protein oxidation, presenting the desired mechanism of action in neurodegenerative disorders. Therefore, we suggest that these alkaloids might be a promising source of lead compounds for drug discovery in the therapies for Alzheimer's and Parkinson's diseases and related processes. However, detailed investigation in vitro and in vivo, including identification of the most effective alkaloids, their mechanisms of action and possible interactions, is necessary.

\section{Acknowledgments}

The authors thank Ms Magdalena Piwowarczyk for technical assistance. This study was supported by the statutory budget of the Mossakowski Medical Research Centre, Polish Academy of Sciences (Theme No. 17) and by a grant from the Polish Ministry of Science and Higher Education, grant no. NN 405362237.

\section{Disclosure}

Authors report no conflict of interest.

\section{References}

1. Armstrong RA. What causes Alzheimer's disease? Folia Neuropathol 2013; 51: 169-188.

2. Asakawa T, Matsushita S. Coloring conditions of thiobarbituric acid test for detecting lipid hydroperoxides. Lipids 1980; 15 : 137-140.

3. Ayer WA, Kasitu GC. Some new Lycopodium alkaloids. Can J Chem-Rev Can Chim 1989; 67: 1077-1086.

4. Ayer WA, Trifonow LS. Lycopodium alkaloids. Academic Press, San Diego 1994.

5. Ayer WA, Browne LM, Orszanska H, Valenta Z, Liu JS. Alkaloids of Lycopodium selago: on the identity of selagine with huperzine $\mathrm{a}$ and the structure of a related alkaloid. Can J Chemistry 1989; 67: 1538-1540.

6. Banerjee J, Biswas S, Madhu NR, Karmakar SR, Biswas SJ. A better understanding of pharmacological activities and uses of phytochemicals of Lycopodium clavatum: a review. J Pharmacogn Phytochem 2014; 3: 207-210.

7. Bastos DHM, Saldanha LA, Catharino RR, Sawaya ACHF, Cunha IBS, Carvalho PO, Eberlin MN. Phenolic antioxidants identifled by ESI-MS from Yerba maté (Ilex paraguariensis) and green tea (Camelia sinensis) extracts. Molecules 2007; 12: 423-432.

8. Bishayee K, Chakraborty D, Ghosh S, Boujedaini N, KhudaBukhsh AR. Lycopodine triggers apoptosis by modulating 5-lipoxygenase, and depolarizing mitochondrial membrane poten- 
tial in androgen sensitive and refractory prostate cancer cells without modulating p53 activity: Signaling cascade and drugDNA interaction. Eur J Pharmacol 2013; 698: 110-121.

9. Blois MS. Antioxidant determinations by the use of a stable free radical. Nature 1958; 181: 1199-1200.

10. Brown DR. Neurodegeneration and oxidative stress: Prion disease results from loss of antioxidant defence. Folia Neuropathol 2005; 43: 229-243.

11. Chen CYO, Ribaya-Mercado JD, McKay DL, Croom E, Blumberg JB. Differential antioxidant and quinone reductase inducing activity of American, Asian, and Siberian ginseng. Food Chemistry 2010; 119: 445-451.

12. Czapski GA, Czubowicz K, Strosznajder RP. Evaluation of the antioxidative properties of lipoxygenase inhibitors. Pharmacol Rep 2012; 64: 1179-1188.

13. Czapski GA, Avram D, Sakharov DV, Wirtz KWA, Strosznajder JB, Pap EHW. Activated neutrophils oxidize extracellular proteins of endothelial cells in culture: Effect of nitric oxide donors. Biochem J 2002; 365: 897-902.

14. Czubowicz K, Czapski GA, Cieslik M, Strosznajder RP. Lipoxygenase inhibitors protect brain cortex macromolecules against oxidation evoked by nitrosative stress. Folia Neuropathol 2010; 48: 283-292.

15. Farhoosh R, Golmovahhed GA, Khodaparast MHH. Antioxidant activity of various extracts of old tea leaves and black tea wastes (Camellia sinensis L.). Food Chemistry 2007; 100: 231236.

16. Ferdinandy P, Schulz R. Inhibition of peroxynitrite-induced dityrosine formation with oxidized and reduced thiols, nitric oxide donors, and purine derivatives. Antioxid Redox Signal 2001; 3 : 165-171.

17. Friedman J. Why is the nervous system vulnerable to oxidative stress? In: Gadoth N, Göbel HH (eds.). Oxidative stress and free radical damage in neurology. Springer Science+Business Media, New York 2011; p. 19-27.

18. Galasko DR, Peskind E, Clark CM, Quinn JF, Ringman JM, Jicha GA, Cotman C, Cottrell B, Montine TJ, Thomas RG, Aisen P; Alzheimer's Disease Cooperative Study. Antioxidants for Alzheimer disease: a randomized clinical trial with cerebrospinal fluid biomarker measures. Arch Neurol 2012; 69: 836-841.

19. Gerard RV, Maclean DB. GC/MS examination of four Lycopodium species for alkaloid content. Phytochemistry 1986; 25 : 1143-1150.

20. Halldorsdottir ES, Jaroszewski JW, Olafsdottir ES. Acetylcholinesterase inhibitory activity of lycopodane-type alkaloids from the Icelandic Lycopodium annotinum ssp. alpestre. Phytochemistry 2010; 71: 149-157.

21. Halldorsdottir ES, Palmadottir RH, Nyberg NT, Olafsdottir ES. Phytochemical analysis of alkaloids from the Icelandic club moss Diphasiastrum alpinum. Phytochem Lett 2013; 6: 355 359.

22. Hatcher H, Planalp R, Cho J, Torti FM, Torti SV. Curcumin: From ancient medicine to current clinical trials. Cellular and molecular life sciences. CMLS 2008; 65: 1631-1652.

23. Hirasawa Y, Morita H, Kobayashi J. Nankakurine A, a novel C16N2-type alkaloid from Lycopodium hamiltonii. Org Lett 2004; 6: 3389-3391.
24. Ishiuchi K, Park JJ, Long RM, Gang DR. Production of huperzine $\mathrm{a}$ and other Lycopodium alkaloids in Huperzia species grown under controlled conditions and in vitro. Phytochemistry 2013; 91: 208-219.

25. Ishiuchi K, Kubota T, Ishiyama H, Hayashi S, Shibata T, Mori K, et al. Lyconadins D and E, and complanadine E, new Lycopodium alkaloids from Lycopodium complanatum. Bioorg Med Chem 2011; 19: 749-753.

26. Jung $\mathrm{CH}$, Seog HM, Choi IW, Choi HD, Cho HY. Effects of wild ginseng (Panax ginseng C.A. Meyer) leaves on lipid peroxidation levels and antioxidant enzyme activities in streptozotocin diabetic rats. J Ethnopharmacol 2005; 98: 245-250.

27. Kobayashi J, Hirasawa Y, Yoshida N, Morita H. Lyconadin A, a novel alkaloid from Lycopodium complanatum. J Org Chem 2001; 66: 5901-5904.

28. Konrath EL, Neves BM, Lunardi PS, Passos Cdos S, Simões-Pires A, Ortega MG, Gonçalves CA, Cabrera JL, Moreira JC, Henriques AT. Investigation of the in vitro and ex vivo acetylcholinesterase and antioxidant activities of traditionally used Lycopodium species from South America on alkaloid extracts. J Ethnopharmacol 2012; 139: 58-67.

29. Li H, Wang X, Lei X. Total syntheses of Lycopodium alkaloids (+)-fawcettimine, (+)-fawcettidine, and (-)-8-deoxyserratinine. Angew Chem Int Ed Engl 2012; 51: 491-495.

30. Ma X, Gang DR. The Lycopodium alkaloids. Nat Prod Rep 2004; 21: 752-772.

31. Ma X, Gang DR. In vitro production of huperzine A, a promising drug candidate for Alzheimer's disease. Phytochemistry 2008; 69: 2022-2028.

32. Ma X, Tan C, Zhu D, Gang DR, Xiao P. Huperzine A from Huperzia species - an ethnopharmacolgical review. J Ethnopharmacol 2007; 113: 15-34.

33. Morita H, Hirasawa Y, Shinzato T, Kobayashi J. New phlegmarane-type, cernuane-type, and quinolizidine alkaloids from two species of Lycopodium. Tetrahedron 2004; 60: 7015-7023.

34. Ning N, Hu JF, Yuan YH, Zhang XY, Dai JG, Chen NH. Huperzine A derivative $M 3$ protects $P C 12$ cells against sodium nitroprusside-induced apoptosis. Acta Pharmacol Sin 2012; 33: 34-40.

35. Oliver CN, Ahn BW, Moerman EJ, Goldstein S, Stadtman ER. Age-related-changes in oxidized proteins. J Biol Chem 1987; 262: 5488-5491.

36. Pan G, Williams RM. Unified total syntheses of fawcettimine class alkaloids: fawcettimine, fawcettidine, lycoflexine, and lycoposerramine B. J Org Chem 2012; 77: 4801-4811.

37. Park JH, Kim RY, Park E. Antioxidant and alpha-glucosidase inhibitory activities of different solvent extracts of skullcap (Scutellaria baicalensis). Food Sci Biotechnol 2011; 20: 11071112.

38. Peng-Fei L, Fu-Gen H, Bin-Bin D, Tian-Sheng D, Xiang-Lin H, Ming-Qin Z. Purification and antioxidant activities of baicalin isolated from the root of huangqin (Scutellaria baicalensis gcorsi). J Food Sci Tech 2013; 50: 615-619.

39. Piotrowski P, Wierzbicka K, Smialek M. Neuronal death in the rat hippocampus in experimental diabetes and cerebral ischaemia treated with antioxidants. Folia Neuropathol 2001; 39: 147-154. 
40. Pocernich CB, Butterfield DA. Elevation of glutathione as a therapeutic strategy in Alzheimer disease. Biochim Biophys Acta 2012; 1822: 625-630.

41. Pradeep H, Diya JB, Shashikumar S, Rajanikant GK. Oxidative stress - assassin behind the ischemic stroke. Folia Neuropatho 2012; 50: 219-230.

42. Ronowicz J, Kupcewicz B, Budzisz E. Chemometric analysis of antioxidant properties of herbal products containing Ginkgo biloba extract. Cent Eur J Biol 2013; 8: 374-385.

43. Shi Q, Fu J, Ge D, He Y, Ran J, Liu Z, Wei J, Diao T, Lu Y. Huperzine A ameliorates cognitive deficits and oxidative stress in the hippocampus of rats exposed to acute hypobaric hypoxia. Neurochem Res 2012; 37: 2042-2052.

44. Singh G, Kapoor IPS, Singh P, de Heluani CS, de Lampasona MP, Catalan CAN. Comparative study of chemical composition and antioxidant activity of fresh and dry rhizomes of turmeric (Curcuma longa Linn.). Food Chem Toxicol 2010; 48: 1026-1031.

45. Staerk D, Larsen J, Larsen LA, Olafsdottir ES, Witt M, Jaroszewski JW. Selagoline, a new alkaloid from Huperzia selago. Nat Prod Res 2004; 18: 197-203.

46. Szypula W, Pietrosiuk A, Suchocki P, Olszowska O, Furmanowa $\mathrm{M}$, Kazimierska O. Somatic embryogenesis and in vitro culture of Huperzia selago shoots as a potential source of huperzine A. Plant Sci 2005; 168: 1443-1452.

47. Szypula WJ, Mistrzak P, Olszowska O. A new and fast method to obtain in vitro cultures of Huperzia selago (Huperziaceae) sporophytes, a club moss which is a source of huperzine A. Acta Soc Bot Pol 2013; 82: 313-320.

48. Szypula WJ, Kiss AK, Pietrosiuk A, Swist M, Danikiewicz W, Olszowska O. Determination of huperzine A in Huperzia selago plants from wild population and obtained in in vitro culture by high-performance liquid chromatography using a chaotropic mobile phase. Acta Chromatogr 2011; 23: 339-352.

49. Takayama H, Katakawa K, Kitajima M, Yamaguchi K, Aimi N. Ten new Lycopodium alkaloids having the lycopodane skeleton isolated from Lycopodium serratum Thunb. Chem Pharm Bull 2003; 51: 1163-1169.

50. Vellas B, Coley N, Ousset PJ, Berrut G, Dartigues JF, Dubois B, Grandjean H, Pasquier F, Piette F, Robert P, Touchon J, Garnier P, Mathiex-Fortunet H, Andrieu S; GuidAge Study Group. Longterm use of standardised Ginkgo biloba extract for the prevention of Alzheimer's disease (GuidAge): a randomised placebo-controlled trial. Lancet Neurol 2012; 11: 851-859.

51. Wang LM, Han YF, Tang XC. Huperzine A improves cognitive deficits caused by chronic cerebral hypoperfusion in rats. Eur J Pharmacol 2000; 398: 65-72.

52. Wang R, Zhang HY, Tang XC. Huperzine A attenuates cognitive dysfunction and neuronal degeneration caused by beta-amyloid protein-(1-40) in rat. Eur J Pharmacol 2001; 421: 149-156.

53. Wang XJ, Li L, Yu SS, Ma SG, Qu J, Liu YB, Li Y, Wang Y, Tang $W$. Five new fawcettimine-related alkaloids from Lycopodium japonicum Thunb. Fitoterapia 2013; 91: 74-81.

54. Wiedenfeld H, Pietrosiuk A, Furmanowa M, Roeder E. Pyrrolizidine alkaloids from Lithospermum canescens Lehm. Z Naturforsch C 2003; 58: 173-176.

55. Wu QQ, Gu YH. Quantification of huperzine A in Huperzia serrata by HPLC-UV and identification of the major constituents in its alkaloid extracts by HPLC-DAD-MS-MS. J Pharm Biomed Anal 2006; 40: 993-998.

56. Xiao XQ, Wang R, Tang XC. Huperzine A and tacrine attenuate beta-amyloid peptide-induced oxidative injury. J Neurosci Res 2000; 61: 564-569.

57. Yang G, Wang Y, Tian J, Liu JP. Huperzine A for Alzheimer's disease: a systematic review and meta-analysis of randomized clinical trials. PloS one 2013; 8: e74916.

58. Yuan C, Chang CT, Axelrod A, Siegel D. Synthesis of (+)-complanadine A, an inducer of neurotrophic factor excretion. J Am Chem Soc 2010; 132: 5924-5925.

59. Zandi PP, Anthony JC, Khachaturian AS, Stone SV, Gustafson D, Tschanz JT, et al. Reduced risk of Alzheimer disease in users of antioxidant vitamin supplements: the Cache County Study. Arch Neurol 2004; 61: 82-88.

60. Zhang HY, Tang XC. Neuroprotective effects of huperzine A: new therapeutic targets for neurodegenerative disease. Trends Pharmacol Sci 2006; 27: 619-625. 